\title{
Action of essential oils from Brazilian native and exotic medicinal species on oral biofilms
}

\author{
Salete MF Bersan ${ }^{1,2}$, Livia CC Galvão', Vivian FF Goes², Adilson Sartoratto², Glyn M Figueira², Vera LG Rehder², \\ Severino M Alencar ${ }^{3}$, Renata MT Duarte ${ }^{2}$, Pedro L Rosalen ${ }^{1}$ and Marta CT Duarte ${ }^{1,2^{*}}$
}

\begin{abstract}
Background: Essential oils (EO) obtained from twenty medicinal and aromatic plants were evaluated for their antimicrobial activity against the oral pathogens Candida albicans, Fusobacterium nucleatum, Porphyromonas gingivalis, Streptococcus sanguis and Streptococcus mitis.

Methods: The antimicrobial activity of the EO was evaluates by microdilution method determining Minimal Inhibitory Concentration. Chemical analysis of the oils compounds was performed by Gas chromatography-mass spectrometry (CG-MS). The most active EO were also investigated as to their actions on the biolfilm formation.

Results: The most of the essential oils (EO) presented moderate to strong antimicrobial activity against the oral pathogens (MIC - Minimal Inhibitory Concentrations values between 0.007 and $1.00 \mathrm{mg} / \mathrm{mL}$ ). The essential oil from Coriandrum sativum inhibited all oral species with MIC values from 0.007 to $0.250 \mathrm{mg} / \mathrm{mL}$, and MBC/MFC (Minimal Bactericidal/Fungicidal Concentrations) from 0.015 to $0.500 \mathrm{mg} / \mathrm{mL}$. On the other hand the essential oil of C. articulatus inhibited $63.96 \%$ of $S$. sanguis biofilm formation. Through Scanning Eletronic Microscopy (SEM) images no changes were observed in cell morphology, despite a decrease in biofilm formation and changes on biofilm structure. Chemical analysis by Gas Chromatography - Mass Spectrometry (GC-MS) of the C. sativum essential oil revealed major compounds derivatives from alcohols and aldehydes, while Cyperus articulatus and Aloysia gratissima (EOs) presented mono and sesquiterpenes.

Conclusions: In conclusion, the crude oil from C. articulatus exhibited the best results of antimicrobial activity e ability to control biofilm formation. The chemical analysis showed the presence of terpenes and monoterpenes such as a-pinene, a-bulnesene and copaene. The reduction of biofilms formation was confirmed from SEM images. The results of this research shows a great potential from the plants studied as new antimicrobial sources.
\end{abstract}

Keywords: Antimicrobial activity, Essential oil and oral biofilm

\section{Background}

The oral cavity is the habitat of several kinds of microorganisms, which form a complex community structure that can adhere to the teeth surface or to mucosal epithelial forming biofilms [1]. Microbial biofilms are communities formed when single cell microorganisms become firmly adhered to a solid surface covered by an extracellular

\footnotetext{
* Correspondence: mduarte@cpqba.unicamp.br

'Department of Physiological Sciences, Piracicaba Dental School, University of Campinas, (UNICAMP), 901 Limeira Av, Zip Code 13414-018 Piracicaba, SP, Brazil

${ }^{2}$ Chemical, Biological and Agricultural Pluridisciplinary Research Center (CPQBA), University of Campinas (UNICAMP), Box. 6171, Zip Code: 13081-970 Campinas, SP, Brazil

Full list of author information is available at the end of the article
}

polysaccharide matrix, and can be formed from multiple or single microbial species [2].

Oral biofilm acquires new microbial species in each stage of its development, including Lactobacillus casei, Streptococcus sanguis, S. mutans, S. mitis and S. sobrinus, which due their pathogenicity could damage the enamel and gum tissue [3]. Diseases appear in this micro-environment when there is a lack of equilibrium in the ecosystem of the bacterial biofilm formed [4], and thus the mechanical removal of the biofilm is an important factor to prevention of caries and periodontal diseases. Since biofilm is an organized association, able to adhere to teeth and causing pathological alterations in oral cavity, its disaggregation is indicated as soon as possible [5]. Considering the importance 
Table 1 Medicinal and aromatic plants from CPMA - "Collection of Medicinal and Aromatic Plants" - CPQBA/UNICAMP selected for this study

\begin{tabular}{|c|c|c|c|c|c|c|}
\hline Medicinal Species & Family & Popular Name & Source & No. CPMA & No. Voucher* & Popular use \\
\hline Aloysia gratissima (Giil \& Hook) & Verbenaceae & Brazilian lavender & leaf & 714 & UEC 121.393 & Digestive antispasmodic \\
\hline Aloysia triphylla (L’Hér.) Britton & Verbenaceae & Aloisia & leaf & $274 / 700$ & UEC 121.412 & Sedative, antispasmodic \\
\hline Alpinia speciosa (Pers.) Burtt \& Smith & Zingiberaceae & Colony & root & 447 & UEC 145.185 & Antimicrobial \\
\hline Baccharis dracunculifolia DC. & Asteraceae & Broom weed & leaf & 1841 & - & Tonic, eupeptic, antipyretic \\
\hline Cinnamomun zeilanicus Blume & Lauraceae & Cinnamon & leaf & 455 & IAC 19624 & Carminative, antispasmodic \\
\hline Coriandrum sativum L. & Apiaceae & Coriander & leaf & 664 & - & Antimicrobial,antifungal \\
\hline Cymbopogon citratus (DC) Stapf & Poaceae & Lemon grass & leaf & 503 & UEC 85.210 & Sedative, analgesic, anti-cough \\
\hline Cymbopogon martini (Roxb.) J.F. Watson & Poaceae & Palmarosa & leaf & 354 & UEC 127.115 & Antiseptic, antifungal \\
\hline Cymbopogon winterianus Jowitt. & Poaceae & Lemon verbena & leaf & 712 & UEC 121.414 & Repellent, insecticide \\
\hline Cyperus articulatus Vahl & Cyperaceae & Piprioca & bulbs & 222 & UEC 121.396 & Anti-inflammatory \\
\hline Elyonurus muticus Spreng & Poaceae & Agripalma & leaf & 1701 & UEC 20.580 & Antibacterial \\
\hline Eugenia florida DC. & Myrtaceae & Guamirin-cereja & leaf & 1685 & IAC 49207 & Anti-inflammatory \\
\hline Eugenia uniflora $L$ & Myrtaceae & Pitanga & leaf & 1816 & - & Anti-hypertensive, diuretic \\
\hline Lippia alba (Mill) N.E. Brown & Verbenaceae & False lemon balm & leaf & $467 / 509$ & UEC 121.413 & Treatment of migraines \\
\hline Lippia sidoides Cham. & Verbenaceae & Rosemary & leaf & $398 / 399$ & - & Bactericide, fungicide \\
\hline Mentha $\times$ piperita $\mathrm{L}$. & Lamiaceae & Mint & leaf & 560 & UEC 127.110 & Antifungal, antibacterial \\
\hline Mikania glomerata Spreng & Asteraceae & Guaco & leaf & 766 & UEC 102.047 & Anti-inflammatory, bronchodilator \\
\hline Siparuna guianenses Aubl. & Monimiaceae & Wild lemon & leaf & 2025 & - & Tranquilizer, diuretic \\
\hline $\begin{array}{l}\text { Syzygium aromaticum (L.) Merr. \& } \\
\text { L. M. Perry }\end{array}$ & Myrtaceae & Cloves & leaf & 455 & IAC 19624 & Seasoning, antibacterial \\
\hline Ziziphus joazeiro mart & Rhamnaceae & Juazeiro fruit & leaf & 2119 & - & Astringent, Anti-inflammatory \\
\hline
\end{tabular}

*Deposited in the herbarium of species with no voucher number are being registered yet.

of this dissociation, it is important to associate both chemical and mechanical procedures in order to control its formation [6].

Antimicrobial substances such as chlorhexidine digluconate has been considered as golden standard when compared to other chemical agents used in dentistry, due its capacity to avoid dental biofilm formation [7]. The main advantage of using chlorhexidine is its wide antimicrobial spectrum, acting on both Gram-positive and Gram-negative microorganisms, and its prolonged and continuous effect even in the presence of blood and other body fluids [8]. However, the prolonged use of chlorhexidine can cause mucous peeling, stains on the teeth, alterations in the sense of taste, compromising of the wounds healing and reduction of fibroblast adhesion to radicular surfaces [9]. Thus a potential antimicrobial adjuvant alternative with less side-effects would be of great value acting on oral affections.

An increasing interest in natural products as a source of new bioactive molecules has been observed in the literature [10]. These include essential oils (EOs) from medicinal and aromatic plants, products of their secondary metabolism. They are characterized as having a very diverse composition derived mainly from two different groups of compounds, the terpenoids (monoterpenes and sesquiterpenes) and phenylpropanoids [11]. These compounds come from different precursors of primary metabolism and are synthesized through different pathways conferring antimicrobial and antifungal properties [12]. The antimicrobial properties of EOs against a wide variety of bacteria and fungi have been shown, including oral pathogens [10,13-15]. Thus, the use of plants as alternative medicine has gained the attention of the scientific community, since this is a promising field for the treatment of pathogens, including those related to the oral cavity. Considering the increased interest in the use of natural products as alternative antimicrobial substances, the aim of this work was to evaluate the activity of EOs from twenty medicinal plants against both planktonic cells and biofilms of oral pathogens as well the chemical composition from the most active oils by GC/MS - Gas Chromatography/Mass Spectrometry analysis and, the possible morphological cells alterations by SEM - Scanning Electronic Microscopy.

\section{Methods}

\section{Microorganisms}

The following oral pathogens were studied: Candida albicans CBS 562 from "Centraalbureau voor Schimmelcultures" and bacteria Streptococcus sanguis ATCC 10556, 
Table 2 Oil yield and antimicrobial activity of the EOs studied against oral pathogens (MIC/MBC/MFC $-\mathrm{mg} / \mathrm{mL}$ )

\begin{tabular}{|c|c|c|c|c|c|c|c|c|c|c|c|}
\hline \multirow{3}{*}{ Medicinal species } & \multirow{3}{*}{$\%$ Yield (\%) } & \multicolumn{10}{|c|}{ Microorganisms } \\
\hline & & \multicolumn{2}{|c|}{$\begin{array}{l}\text { C. albicans } \\
\text { CBS } 562\end{array}$} & \multicolumn{2}{|c|}{$\begin{array}{l}\text { F. nucleatum } \\
\text { ATCC } 25586\end{array}$} & \multicolumn{2}{|c|}{$\begin{array}{l}\text { P. gingivalis } \\
\text { ATCC } 33277\end{array}$} & \multicolumn{2}{|c|}{$\begin{array}{l}\text { S. sanguis } \\
\text { ATCC } 10556\end{array}$} & \multicolumn{2}{|c|}{$\begin{array}{l}\text { S. mitis } \\
\text { ATCC } 903\end{array}$} \\
\hline & & MIC & MFC & MIC & MBC & MIC & MBC & MIC & MBC & MIC & MBC \\
\hline Aloysia gratissima (Aff \& Hook).Tr & 1.10 & 0.015 & 0.062 & 0.125 & 0.250 & 0.125 & 0.125 & 0.500 & 1.000 & 0.250 & 0.250 \\
\hline Aloysia triphylla (L'Hér.) Britton & 0.27 & 0.015 & 0.062 & 0.125 & 0.250 & 0.250 & 0.250 & 0.500 & 1.000 & 0.500 & 0.500 \\
\hline Alpinia speciosa (Pers.) Burtt \& Smith & 0.22 & 0.007 & 0.062 & 0.125 & 0.125 & 0.125 & 0.250 & 0.500 & * & 0.500 & * \\
\hline Baccharis dracunculifolia DC. & 0.80 & 0.250 & 0.500 & 0.125 & 0.250 & 0.125 & 0.125 & 0.500 & 0.500 & 0.250 & 0.250 \\
\hline Cinnamomun zeilanicus Blume & 0.22 & 0.007 & 0.007 & 0.250 & 0.250 & 0.250 & 0.250 & 0.500 & 1.000 & 0.500 & 0.500 \\
\hline Coriandrum sativum $L$. & 0.29 & 0.007 & 0.015 & 0.015 & 0.125 & 0.125 & 0.125 & 0.250 & 0.500 & 0.062 & 0.125 \\
\hline Cymbopogon citratus (DC) Stapf & 1.13 & 0.015 & 0.125 & 0.250 & 0.250 & 0.250 & 0.250 & 0.500 & * & 0.250 & 0.500 \\
\hline Cymbopogon. martini (Roxb.) J.F. Watson & 0.59 & 0.015 & 0.125 & 0.125 & 0.250 & 0.250 & 0.250 & 0.500 & * & 0.250 & 0.250 \\
\hline Cymbopogon. winterianus Jowitt. & 1.48 & 0.015 & 0.125 & 0.125 & 0.250 & 0.250 & 0.500 & 0.500 & * & 0.250 & 0.500 \\
\hline Cyperus articulatus $L$. & 0.50 & 0.125 & 0.500 & 0.250 & 0.250 & 0.250 & 0.250 & 0.250 & 0.500 & 0.250 & 0.500 \\
\hline Elyonurus muticus Spreng. & 0.61 & 0.250 & * & 0.250 & 0.500 & 0.250 & 0.250 & 0.500 & 1.000 & 0.500 & * \\
\hline Eugenia florida $D C$. & 0.34 & 0.125 & * & 0.125 & 0.250 & 0.125 & * & 0.125 & 0.250 & 0.500 & 0.500 \\
\hline Eugenia uniflora $L$ & 0.76 & 0.250 & * & 0.125 & 0.125 & 0.250 & 0.250 & 0.500 & 0.500 & 0.500 & 0.500 \\
\hline Lippia alba (Mill) N.E. Brown & 0.30 & 0.250 & 0.500 & 0.125 & 0.125 & 0.250 & 0.250 & 0.250 & 1.000 & 0.250 & * \\
\hline L. sidoides Cham. & 4.67 & 0.250 & 0.500 & 0.125 & 0.125 & 0.250 & 0.250 & 0.125 & 0.500 & 0.250 & * \\
\hline Mentha piperita $L$. & 2.22 & 0.500 & * & 0.250 & 0.250 & 0.250 & $*$ & 0.500 & 0.500 & 0.500 & 0.500 \\
\hline Mikania glomerata Spreng & 0.40 & 0.250 & 0.250 & 0.250 & 0.500 & 0.500 & * & 0.062 & 0.125 & 0.125 & 0.125 \\
\hline Siparuna guianenses Aubl & 0.29 & 0.125 & 0.250 & 0.062 & 0.250 & 0.062 & 0.125 & 0.250 & 1.000 & 0.125 & 0.250 \\
\hline Syzygium aromaticum (L.) Merr. \& L. M. Perry & 0.46 & 0.500 & 0.500 & 0.250 & 0.250 & 0.250 & 0.250 & 0.500 & 1.000 & 0.500 & 0.500 \\
\hline Ziziphus joazeiro mart & 0.46 & 1.000 & * & 0.250 & 0.500 & 0.250 & 0.250 & 0.500 & 1.000 & 0.500 & 0.500 \\
\hline Nystatin & - & 0.007 & 0.015 & - & - & - & - & - & - & - & - \\
\hline Chlorhexidine digluconate & & - & - & 0.015 & 0.015 & 0.015 & 0.125 & 0.015 & 0.015 & 0.015 & 0.125 \\
\hline
\end{tabular}

*Fungicidal/bactericidal action: MIC > $1 \mathrm{mg} / \mathrm{mL}$.

Streptococcus mitis ATCC 903, Porphyromonas gingivalis ATCC 33277 and Fusobacterium nucleatum ATCC 25586 from American Type Culture Collection. The microorganisms were stored at $-70^{\circ} \mathrm{C}$ in Sabouraud Dextrose Broth (SDB, Merck - C. albicans) and Mueller-Hinton Broth (Difco ${ }^{\circ}$ - bacteria) with $15 \%$ glycerol. It was considered the oxygen exigencies of each microorganism (C. albicans aerobiosis, $S$. mitis and S. sanguis microaerophilie and $F$. nucleatum and $P$. gingivalis anaerobiosis) to choose bacteria growth conditions.

\section{Plant material}

Twenty medicinal and aromatic species choose for this study were belonging to "Collection of Medicinal and Aromatic Plants" - CPMA of the Research Center for Chemistry, Biology and Agriculture (CPQBA), University of Campinas (UNICAMP), Campinas, SP, Brazil (http://www.cpqba.unicamp.br/), with the vouchers numbers indicated in Table 1. Samples were collected in spring/summer from November 2009 to January 2011, in the morning after dew point. The exsiccates from plant material used in this study are deposited in the herbarium of the Institute of Biology at UNICAMP - UEC and were identified by Dr. Washington Marcondes Ferreira Neto (curator). The species were deposited in the.

\section{EO extraction}

The EOs were obtained from $100 \mathrm{~g}$ of fresh plant parts by water distillation for $3 \mathrm{~h}$ using a Clevenger-type system. After completion of this process, the system was cooled and the aqueous phase collected followed by washing of all the Clevenger apparatus with dichloromethane $(50 \mathrm{ml})$ to obtain the EOs.The pooled organic phases were dried with sodium sulfate, filtered, and the solvent evaporated until dryness. The oil samples were stored at $-25^{\circ} \mathrm{C}$ in sealed glass vials [16].

\section{Fractionation of EOs}

For the fractionation, the oils were selected based on criteria such as good antimicrobial activity (MIC until $0.5 \mathrm{mg} / \mathrm{mL}$ [17], oil yield ( $>0.5 \%$, except for C. sativum and $M$. glomerata), seasonal cultivation of the plants and 
Table 3 Antimicrobial activity of the crude EO and their fractions against oral pathogens (MIC/MBC/MFC $-\mathrm{mg} / \mathrm{mL}$ )

\begin{tabular}{|c|c|c|c|c|c|c|c|c|c|c|c|}
\hline \multirow{3}{*}{ Medicinal species } & \multirow{3}{*}{$\%$ Yield fraction } & \multicolumn{10}{|c|}{ Microorganisms } \\
\hline & & \multicolumn{2}{|c|}{$\begin{array}{l}\text { C. albicans } \\
\text { CBS } 562\end{array}$} & \multicolumn{2}{|c|}{$\begin{array}{l}\text { F. nucleatum } \\
\text { ATCC } 25586\end{array}$} & \multicolumn{2}{|c|}{$\begin{array}{l}\text { P. gingivalis } \\
\text { ATCC } 33277\end{array}$} & \multicolumn{2}{|c|}{$\begin{array}{l}\text { S. sanguis } \\
\text { ATCC } 10556\end{array}$} & \multicolumn{2}{|c|}{$\begin{array}{l}\text { S. mitis } \\
\text { ATCC } 903\end{array}$} \\
\hline & & MIC & $\overline{\text { MFC }}$ & MIC & MBC & $\overline{M I C}$ & $\overline{M B C}$ & MIC & $\overline{M B C}$ & MIC & MBC \\
\hline EO A. gratissima & & 0.015 & 0.062 & 0.125 & 0.250 & 0.125 & 0.125 & 0.500 & 1.000 & 0.250 & 0.250 \\
\hline$F_{1} A G$ & 25.70 & 0.500 & 1.000 & 0.500 & 0.500 & 0.250 & 0.500 & 0.500 & 1.000 & 0.250 & 0.500 \\
\hline$F_{2} A G$ & 11.12 & 0.500 & * & 0.500 & 0.500 & 0.250 & 0.500 & 0.500 & 1.000 & 0.500 & 0.500 \\
\hline$F_{3} A G$ & 26.94 & 0.500 & 1.000 & 0.250 & 0.500 & 0.250 & 0.500 & 0.500 & 0.500 & 0.250 & 0.500 \\
\hline$F_{4} A G$ & 16.48 & 0.125 & * & 0.062 & 0.250 & 0.125 & 0.500 & 0.125 & 0.125 & 0.125 & 0.125 \\
\hline EO C. sativum & & 0.007 & 0.015 & 0.015 & 0.125 & 0.125 & 0.125 & 0.250 & 0.500 & 0.063 & 0.125 \\
\hline$F_{7} C S$ & 24.88 & 0.500 & 1.000 & 0.250 & 0.250 & 0.125 & 0.500 & 0.500 & 0.500 & 0.500 & 0.500 \\
\hline$F_{2} C S$ & 39.20 & 0.250 & 1.000 & 0.125 & 0.250 & 0.125 & 0.500 & 0.500 & 0.500 & 0.250 & 1.000 \\
\hline$F_{3} C S$ & 15.20 & 0.250 & 1.000 & 0.250 & 0.250 & 0.125 & 0.500 & 0.500 & * & 0.250 & 1.000 \\
\hline$F_{4} C S$ & 9.20 & 0.250 & 1.000 & * & * & 0.500 & 1.000 & 0.500 & 1.000 & 0.500 & * \\
\hline EO C. articulatus & & 0.125 & 0.500 & 0.250 & 0.250 & 0.250 & 0.250 & 0.250 & 0.500 & 0.250 & 0.500 \\
\hline$F_{7} C A$ & 9.20 & 0.250 & 1.000 & 0.250 & * & 0.125 & 0.250 & * & * & 0.500 & * \\
\hline$F_{2} C A$ & 9.41 & 0.250 & * & 0.250 & 0.250 & 0.500 & 1.000 & 1.000 & * & 0.500 & * \\
\hline$F_{3} C A$ & 24.51 & 0.250 & * & 0.250 & 0.250 & 0.250 & 1.000 & 0.500 & 1.000 & 0.250 & 0.500 \\
\hline$F_{4} C A$ & 26.16 & 0.250 & 1.000 & 0.125 & 0.250 & 0.250 & 0.250 & 0.250 & 0.500 & 0.250 & 0.250 \\
\hline EO M. glomerata & & 0.250 & 0.250 & 0.250 & 0.500 & 0.500 & * & 0.062 & 0.125 & 0.125 & 0.125 \\
\hline$F_{1} M G$ & 42.80 & 0.250 & * & 0.250 & 0.500 & 0.250 & 0.500 & * & * & 0.500 & * \\
\hline$F_{2} M G$ & 14.00 & 0.250 & 0.500 & 0.250 & * & 0.500 & 0.500 & * & * & 0.500 & 1.000 \\
\hline$F_{3} M G$ & 7.20 & 0.250 & 1.000 & 0.250 & $*$ & 0.250 & 0.500 & * & $*$ & $*$ & * \\
\hline$F_{4} M G$ & 2.56 & 0.250 & 1.000 & 0.250 & * & 0.250 & 0.250 & 0.250 & 1.000 & 0.250 & 0.500 \\
\hline EO L. sidoides & & 0.250 & 0.500 & 0.125 & 0.125 & 0.250 & 0.250 & 0.125 & 0.500 & 0.250 & * \\
\hline$F_{1} L S$ & 31.96 & 0.250 & * & 0.062 & 0.250 & 0.250 & * & 0.500 & 0.500 & 0.250 & * \\
\hline$F_{2} L S$ & 43.12 & 0.500 & 1.000 & 0.031 & 0.250 & 0.125 & * & 0.125 & 0.250 & 0.125 & 0.125 \\
\hline$F_{3} L S$ & 13.34 & 0.500 & 0.500 & 0.062 & 0.250 & 0.250 & 0.500 & 0.250 & 0.250 & 0.125 & 0.250 \\
\hline$F_{4} L S$ & 4.96 & 0.250 & 1.000 & 0.125 & 0.250 & 0.250 & * & 0.250 & 0.500 & 0.250 & * \\
\hline Nystatin/ & & 0.007 & 0,015 & - & - & - & - & - & - & - & - \\
\hline chlorhexidine digluconate & & - & - & 0.015 & 0.015 & 0.015 & 0.125 & 0.015 & 0.015 & 0.015 & 0.125 \\
\hline
\end{tabular}

*Fungicidal/bactericidal action: MIC > $1 \mathrm{mg} / \mathrm{mL}$,

AG: A. gratissima, CA: C. articulatus, CS: C. sativum, MG: M. glomerata, LS: L. sidoides.

potential production on commercial scale. The Eos $(500 \mathrm{mg}$ ) were fractioned on a dry column (acetate cellulose $2 \mathrm{~cm} \mathrm{X}$ $20 \mathrm{~cm})$ prepared with silica gel $60(20 \mathrm{gr} / 0,063-0,200 \mathrm{~mm})$ (Merck) by direct application onto the packed column, followed by elution. Dichloromethane was previously defined as mobile phase for the fractionation of the oils by TLC (Thin-Layer Chromatography) analysis of each EO using different eluents. After elution, the column was cut in different parts for each EO, and the fractions were individually transferred to appropriate flasks, dissolved in dichloromethane and re-analyzed by TLC. Fractions with similar chemical pattern were grouped resulting in fractions named F1, F2, F3 and F4 in order of increasing polarity. The resulting fractions were filtered under vacuum and the silica residue extracted with dichloromethane [16]. The fractions were analyzed using Gas chromatography coupled to mass spectrometry (GC-MS) and then used antimicrobial assays. All chemical wastes produced in the present study were treated according to the approval of Environmental Ethics Committee of UNICAMP $(322 / 2009)$.

\section{Chemical Constituents of EOs and fractions - Gas chromatography-mass spectrometry (GC-MS)}

The volatile constituents of the EOs oils were determined using a Hewlett-Packard 6890 gas chromatograph, equipped with a HP-5975 mass selective detector and HP-5MS capillary column $(30 \mathrm{~m} \times 0.25 \mathrm{~mm} \times 0.25 \mu \mathrm{m}$ diameter $)$. GC and GC-MS were carried out using split (1:30) injection, with injector temperature set at $220^{\circ} \mathrm{C}$, column at $60^{\circ} \mathrm{C}$, a heating 
Table 4 Antimicrobial activity of the EO against biofilms (72 h) and MBC/MFC:MIC ratio

\begin{tabular}{|c|c|c|c|c|c|c|c|c|c|c|c|c|c|c|c|}
\hline \multirow{3}{*}{ Medicinal species } & \multicolumn{15}{|c|}{ Microorganisms } \\
\hline & \multicolumn{3}{|c|}{ C. albicans CBS 562} & \multicolumn{3}{|c|}{ F. nucleatum ATCC 25586} & \multicolumn{3}{|c|}{ P. gingivalis ATCC 33277} & \multicolumn{3}{|c|}{ S. sanguis ATCC 10556} & \multicolumn{3}{|c|}{ S. mitis ATCC 903} \\
\hline & MIC & MFC & Ratio & MIC & $M B C$ & Ratio & MIC & $M B C$ & Ratio & MIC & $M B C$ & Ratio & MIC & $M B C$ & Ratio \\
\hline A. gratissima & 0.500 & * & ND & 0.500 & 0.500 & $1: 1$ & 0.125 & * & ND & 0.500 & 1.000 & $2: 1$ & 0.250 & 0.500 & $2: 1$ \\
\hline$F_{4} A G$ & 0.500 & * & ND & 0.250 & 1.000 & $4: 1$ & 0.500 & * & ND & 0.500 & 0.500 & $1: 1$ & 0.250 & * & ND \\
\hline C. sativum & 0.250 & 1.000 & $4: 1$ & 0.250 & * & ND & 0.500 & * & ND & 0.500 & * & ND & 0.500 & * & ND \\
\hline M. glomerata & 0.500 & 0.500 & $1: 1$ & 0.250 & * & ND & 1.000 & * & ND & 0.500 & * & ND & 0.500 & * & ND \\
\hline$F_{4} M G$ & 1.000 & 1.000 & $1: 1$ & 0.500 & 1.000 & $2: 1$ & * & * & ND & 0.500 & 0.500 & 1:1 & 0.500 & $*$ & ND \\
\hline C. articulatus & 0.250 & 0.250 & $1: 1$ & 0.250 & 0.500 & $2: 1$ & 0.250 & 0.500 & $2: 1$ & 0.250 & 0.500 & $2: 1$ & 0.500 & 1.000 & $2: 1$ \\
\hline $\mathrm{F}_{4} \mathrm{CA}$ & 1.000 & * & ND & 0.250 & * & ND & * & * & ND & 0.500 & 0.500 & $1: 1$ & 0.500 & $*$ & ND \\
\hline L. sidoides & 0.500 & 1.000 & $2: 1$ & 0.500 & 1.000 & $2: 1$ & 0.500 & * & ND & 0.250 & 0.500 & $2: 1$ & 0.500 & * & ND \\
\hline$F_{2} L S$ & 0.500 & * & ND & 0.250 & 1.000 & $4: 1$ & 0.250 & * & ND & 0.250 & 0.500 & $2: 1$ & 0.500 & * & ND \\
\hline Nystatin & 1.000 & * & ND & - & - & - & - & - & - & & & - & - & - & - \\
\hline Chlorhexidine & - & - & - & 0.015 & 0.125 & $8: 1$ & 0.015 & 0.125 & $8: 1$ & 0.015 & 0.015 & 1:1 & 0.015 & 0.062 & $4: 1$ \\
\hline
\end{tabular}

*Fungicidal/bactericidal action: MIC $>1 \mathrm{mg} / \mathrm{mL}$.

ND- Not determined.

Ratio: MBC:MIC or MFC:MIC between 1:1-2:1 - bactericidal or fungicidal effect, while ratio >2:1 -a bacteriostatic or fungistatic effect.

ramp of $3^{\circ} \mathrm{C} \min ^{-1}$ to a final temperature of $240^{\circ} \mathrm{C}$, and the MS and FID detectors set at $250^{\circ} \mathrm{C}$. Helium was used as the

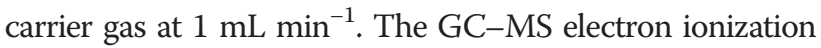
system was set at $70 \mathrm{eV}$. A sample of the $\mathrm{EO}$ was dissolved in ethyl acetate for the analyses. Retention indices (RI) relative to $n$-alkanes were calculated by linear interpolation. Oils components were identified by comparision of experimental RI with reference data [18], by maching mass spectra with NIST software $05^{\circ}$ reference spectra and by injection of authentic standards, when available.

\section{Microbiological assays}

Inocula preparation

Candida albicans, S. sanguis, S. mitis, $P$. gingivalis and F. nucleatum were grown overnight at $36^{\circ} \mathrm{C}$ in Sabouraud Dextrose Broth (SDB, Merck ${ }^{\circ}$ ) and Mueller-Hinton Broth $\left(\mathrm{Difco}^{\oplus}\right)$, respectively. The inocula were prepared according to CLSI protocols M27-A2 and M7-A6 (CLSI 2002, 2005) $[19,20]$. The cells were diluted in $0.85 \% \mathrm{NaCl}$ solution and the suspension turbidity adjusted to 0.5 on the McFarland scale and confirmed in a spectrophotometer (Shimadzu UV mini 1240 Spectrophometer) at $530 \mathrm{~nm}$ (C. albicans) or $625 \mathrm{~nm}$ (bacteria) to absorbance between 0.08-0.1 $\left(10^{6}\right.$ cells $/ \mathrm{mL}$ for yeast and $10^{8}$ cells $/ \mathrm{mL}$ for bacteria). The cell suspensions were finally diluted to $10^{4}$ cells $/ \mathrm{mL}$ for (yeast) or $10^{6}$ cells $/ \mathrm{mL}$ (bacteria).

\section{Minimal Inhibitory Concentration (MIC) of the EOs}

The MIC was determined using tissue culture microplates (96 wells) containing $100 \mu \mathrm{L}$ of Brain Heart Infusion (BHI - Oxoib $^{\oplus}$ ), culture medium for bacteria and Sabouraud Dextrose Broth (SDB, Merck ${ }^{\bullet}$ ) for C. albicans. The stock solutions of EOs oils and fractions were diluted to $4 \mathrm{mg} / \mathrm{mL}$ with propylene glycol, transferred to the first well and serial dilutions were performed to reach concentrations ranging from 1.0-0.00048 mg/mL. Nystatin $\left(\right.$ Sigma $\left.^{\oplus}-1 \%\right)$ and chlorhexidine digluconate (Sigma ${ }^{\odot}$ $0.12 \%)$ were used as antimicrobial standard. The inocula $(100 \mu \mathrm{L})$ was added to all the wells, and the plates incubated at $36^{\circ} \mathrm{C}$ for $48 \mathrm{~h}$ in aerobic, microaerophilic or anaerobic conditions. The MIC was defined as the lowest concentration of the EO able to prevent the microbial growth. The tests were performed in three independent experiments, each one in triplicate $[19,20]$.

\section{Minimal Bactericidal/Fungicidal Concentration (MBC/MFC) of the EOs}

Based on the MIC results $10 \mu \mathrm{L}$ of the cells suspension from the wells showing no visible microbial growth and from three wells above them were subcultured in Petri dishes containing Sabouraud Dextrose Agar medium (SDA- Merck ${ }^{\ominus}$ ) for yeasts and Tryptic Soy Agar (TSADifco $^{\circ}$ ) or Blood Agar media for bacteria. The plates were incubated at $36^{\circ} \mathrm{C}$ until five days in aerobic, microaerophilic or anaerobic conditions. The MBC/MFC was defined as the lowest sample concentration showing no cell growth on the inoculated agar surface. The tests were performed in three independent experiments, each one in triplicate $[19,20]$. The EOs and fractions antimicrobial activity was classified in strong, moderate or weak according to Duarte et al. [17].

\section{Biofilms assays}

\section{Mode of action of the EOs on biofilm}

The method employed for biofilm studies was carried out according to described in the antimicrobial assays 
Table 5 Compounds identified in the active EO and fractions

\begin{tabular}{|c|c|c|c|c|c|c|c|c|c|c|}
\hline Compounds $^{\mathrm{a}}$ & $\mathrm{RI}^{\mathrm{b}}$ & $A G^{c}$ & CA & CS & MG & LS & $\mathrm{F}_{4} \mathrm{AG}$ & $\mathrm{F}_{4} \mathrm{CA}$ & $\mathrm{F}_{4} \mathrm{MG}$ & $F_{2}$ LS \\
\hline Z-3-hexen-1-ol & 857 & & & 5.11 & & & & & & \\
\hline E-2-hexen-1-ol & 868 & & & 2.17 & & & & & & \\
\hline Cyclohexanone & 899 & & & & & 6.50 & & & & \\
\hline Nonane & 901 & & & 2,70 & & & & & & \\
\hline a-pinene & 933 & & 5.72 & & & & & & & \\
\hline b-pinene & 977 & 12.01 & 3.52 & & & & & & & \\
\hline p-cymene & 1024 & & 0.73 & & & 17.28 & & & & \\
\hline Limonene & 1027 & 1.51 & 1.12 & & 2.06 & & & & & \\
\hline Linalool & 1101 & 0.49 & & 0.77 & & & 2.62 & & & \\
\hline E-pinocarveol & 1138 & 2.96 & 4.44 & & & & 13.16 & 21.97 & & \\
\hline E-verbenol & 1144 & 1.59 & 2.38 & & & & & 8.43 & & \\
\hline E-sabinol & 1145 & & & & & & 4.29 & & & \\
\hline E-pinocamphone & 1161 & 16.07 & & & & & 0.84 & & & \\
\hline a-phellandrene-8-ol & 1167 & & 1.75 & & & & & & & \\
\hline p-menta-1,5-dien-8-ol & 1169 & & 0.67 & & & & & 8.97 & & \\
\hline Z-pinocanphone & 1173 & 6.04 & & & & & 0.46 & & & \\
\hline p-cymen-8-ol & 1186 & & 0.51 & & & & 0.93 & 2.97 & & \\
\hline a-terpineol & 1192 & & 0.30 & & & & 0.95 & 2.17 & & \\
\hline Myrtenal & 1195 & & 2.37 & & & & & 9.18 & & \\
\hline Myrtenol & 1196 & 1.81 & 2.13 & & & & 5.31 & & & \\
\hline Verbenone & 1208 & & 1.67 & & & & & 9.73 & & \\
\hline E-carveol & 1220 & & & & & & 1.06 & 2.29 & & \\
\hline Geraniol & 1264 & & & & & & & & & \\
\hline 1-decanol & 1269 & & & 33,91 & & & & & & \\
\hline E-2-decen-1-ol & 1271 & & & 23,59 & & & & & & \\
\hline Geranial & 1272 & & & & & & & & & \\
\hline Thymol & 1290 & & & & & 65.76 & & 0.60 & & 97.20 \\
\hline E-pinocarveol acetate & 1299 & 8.19 & & & & & & & & \\
\hline a-copaene & 1373 & & 4.97 & & 0.76 & & & & & \\
\hline a-caryophyllene & 1416 & 7.19 & & & 9.49 & 10.46 & & & & \\
\hline a-guaiene & 1436 & & 2.17 & & & & & & & \\
\hline 2-dodecen-1-ol & 1469 & & & 13,06 & & & & & & \\
\hline g-muurolene & 1477 & 3.79 & & & & & & & 3.39 & \\
\hline Germacrene D & 1481 & & & & 38.29 & & & & & \\
\hline b-selinene & 1482 & & 2.96 & & & & & & & \\
\hline a-selinene & 1491 & & 2.46 & & & & & & & \\
\hline Bicyclogermacrene & 1493 & 4.20 & & & 7.98 & & & & & \\
\hline a-bulnesene & 1503 & & 5.02 & & & & & & & \\
\hline Elemol & 1547 & 0.48 & & & 0.94 & & 1.64 & & 7.39 & \\
\hline Germacrene B & 1552 & & & & 3.35 & & & & & \\
\hline Sphatulenol & 1574 & 1.54 & & & 3.65 & & 3.96 & & 4.31 & \\
\hline Caryophyllene oxide & 1578 & 2.60 & 3.41 & & 4.28 & & 1.85 & 0.55 & 5.63 & 0.50 \\
\hline Guaiol & 1596 & 8.53 & & & & & 29.63 & & & \\
\hline |solongifolan-7-a-ol & 1620 & & & & 1.21 & & & & 11.58 & \\
\hline
\end{tabular}


Table 5 Compounds identified in the active EO and fractions (Continued)

\begin{tabular}{|c|c|c|c|c|c|c|c|c|c|c|}
\hline Muurola-4,10-dien-1-b-ol & 1628 & & & & 3.59 & & & & 10.42 & \\
\hline a-muurolol & 1646 & & & & & & 0.77 & & 3.45 & \\
\hline b-cadinol & 1652 & & & & 3.47 & & & & 25.85 & \\
\hline Bulnesol & 1665 & 3.14 & & & & & 11.79 & & & \\
\hline Tetradecanol & 1670 & & & 2,92 & & & & & & \\
\hline E-2-tetradecen-1-ol & 1674 & & & 5,46 & & & & & & \\
\hline Mustakone & 1675 & & 5.66 & & & & & & & \\
\hline Ishwarone & 1680 & & 1.51 & & & & & 8.80 & & \\
\hline Germacra-4(15),5,10(14)-trien-1-a-ol & 1684 & & & & & & & & 5.13 & \\
\hline Eudesma-4(15),7-dien-1-b-ol & 1685 & & & & & & & & 9.85 & \\
\hline Others compounds identified <2\% & - & 10.21 & 7.58 & 8.04 & 8.32 & - & 6.55 & 7.39 & 3.77 & 2.31 \\
\hline Total & & 92.35 & 63.05 & 97.73 & 87.39 & 100 & 86.04 & 85.18 & 90.56 & 99.80 \\
\hline
\end{tabular}

(MIC) with modifications. The inocula from cultures were prepared at $10^{7}$ cells $/ \mathrm{mL}$ for bacteria and $10^{5}$ cells/ $\mathrm{mL}$ for $C$. albicans in $\mathrm{BHI}$ or SDB media, respectively, enriched with $2 \%$ sucrose. The cultures were incubated at $36^{\circ} \mathrm{C}$ for $72 \mathrm{~h}$ under appropriate atmosphere in order to promote microbial adherence to the bottom of the wells. Subsequently, MIC values were confirmed and to determine $\mathrm{MBC} / \mathrm{MFC}$, each adhered biofilm was transferred by swab technique to the surface of blood agar or SDA agar in petri dishes and incubated at $30^{\circ} \mathrm{C}$ for until five days according to oxygen microorganisms requirements $[19,20]$. The $\mathrm{MIC} / \mathrm{MBC} / \mathrm{MFC}$ values were used to determine the MBC:MIC or MFC:MIC ratio, as previously proposed by Hafidh et al. [21] to establish the nature of antimicrobial effect, regard to inhibition or killing of the tested microorganisms.

\section{Effect of the EOs and fractions on biofilm formation}

The biofilms were carried out using sterile untreated 96-well polyethylene U-bottom plates (IPT) containing the specific medium (Sabouraud for yeast and BHI for bacteria) enriched with $2 \%$ sucrose. The EOs and fractions were diluted with propylene glycol $(4 \mathrm{mg} / \mathrm{mL})$, transferred to the first well and serial dilutions were performed to reach concentrations ranging from $1.0-0.0048 \mathrm{mg} / \mathrm{mL}$. The $1 \%$ Nystatin $\left(\right.$ Sigma $\left.^{\circ}\right)$ and $0.12 \%$ chlorhexidine digluconate $\left(\right.$ Sigma $\left.^{\circ}\right)$ solutions were used as antibiotic standard. After this procedure, microbial cells $\left(1.0 \times 10^{5}\right.$ cells $/ \mathrm{mL}$ for yeasts and $1.0 \times 10^{7}$ cells $/ \mathrm{mL}$ for bacteria) were added to the wells and the plates were incubated at $36^{\circ} \mathrm{C}$ for $72 \mathrm{~h} \mathrm{[22].}$

\section{Biofilm quantification}

Following biofilm formation the medium was aspirated and no adhered cells were removed by washing the wells twice with $200 \mu \mathrm{L}$ of distilled water. The plates were then dried at room temperature for $45 \mathrm{~min}$. One hundred microliters of a $0.4 \%$ crystal violet solution was added to all the wells. After $45 \mathrm{~min}$, the biofilms formed in the bottom of the wells were washed four times with distilled water and immediately distained with $200 \mu \mathrm{L}$ of $95 \%$ ethanol. After a further $45 \mathrm{~min}, 100 \mu \mathrm{L}$ of well solution were transferred to a well in a new plate and the absorbance measured at $595 \mathrm{~nm}$ in a microplates reader (Asys - Expert Plus). The amount of biofilm formed was calculated by subtracting the absorbance values from control well [23].

\section{Scanning Electron Microscopy (SEM) of biofilms}

In order to assess the integrity of the microbial cells, biofilms were developed in a Lab-Tek TM coverslip chambers (Nunc) as described above, and treated with standard drugs and EOs at $1 \mathrm{mg} / \mathrm{mL}$. The samples were washed twice with $3 \%$ glutaraldehyde in phosphate buffer ( $\mathrm{pH}$ 7.4) and fixed in glutaraldehyde $0.15 \mathrm{M}$ $2.5 \%(\mathrm{v} / \mathrm{v})$ at room temperature for $12 \mathrm{~h}$. The dehydrated cells were submitted to sequential baths of ethanol at concentrations of $50 \%, 70 \%, 90 \%$ and absolute ethanol twice, until the dried at the critical point, then coated with gold in a Metalizer and observed using a Scanning Electron Microscope (Jeol model JSM 5600 Lv) [24].

\section{Statistical analysis}

Statistical analysis was performed with one-way ANOVA and $\mathrm{p}$-values $\leq 0.05$ considered statistically significant. The inhibition of biofilm formation data were compared by Tukey test. The statistical test was run using STATISTICA ${ }^{\oplus}$ v.8.0 (Stafsoft, USA) system software. 
Table 6 Inhibition of biofilm formation (\%) of the oral microorganisms in the presence of the EOs and fractions at $1 \mathrm{mg} / \mathrm{mL}$

\begin{tabular}{|c|c|c|c|c|c|}
\hline \multicolumn{6}{|l|}{ Microorganisms } \\
\hline Medicinal species & $\begin{array}{l}\text { C.albicans } \\
\text { CBS } 562\end{array}$ & $\begin{array}{l}\text { F. nucleatum } \\
\text { ATCC } 25586\end{array}$ & $\begin{array}{l}\text { P. gingivalis } \\
\text { ATCC } 33277\end{array}$ & $\begin{array}{l}\text { S. sanguis } \\
\text { ATCC } 10556\end{array}$ & $\begin{array}{l}\text { S. mitis } \\
\text { ATCC } 903 \\
\end{array}$ \\
\hline EO A .gratissima & $12.31_{\mathrm{f}}$ & $55.83 \mathrm{~d}$ & 39.12 a & $60.83 a, b$ & 9.00 a \\
\hline$F_{4} A G$ & $19.23 \mathrm{~d}, \mathrm{e}$ & $56.46 d$ & $30.88 b$ & $58.13 \mathrm{~b}, \mathrm{c}$ & $8.50 \mathrm{a}$ \\
\hline EO C. sativum & $23.08_{c, d}$ & $55.83 \mathrm{~d}$ & 39.71 a & $58.33 a, b, c$ & $1.50 \mathrm{~b}$ \\
\hline EO M. glomerata & $22.69 c, d$ & $58.96 c$ & $40.00 \mathrm{a}$ & $54.79 c$ & $1.00 \mathrm{~b}$ \\
\hline$F_{4} M G$ & $20.77_{d, e}$ & $60.83 \mathrm{~b}$ & 37.94 a & $60.63 a, b, c$ & $0.00 c$ \\
\hline EO C. articulatus & $28.08 a, b$ & $61.67 a, b$ & $43.53 a$ & $63.96 a$ & $5.00 \mathrm{a}, \mathrm{b}$ \\
\hline $\mathrm{F}_{4} \mathrm{CA}$ & $25.77 \mathrm{a}, \mathrm{b}, \mathrm{c}$ & $61.25 \mathrm{a}, \mathrm{b}$ & 39.41 a & $61.67 \mathrm{a}, \mathrm{b}$ & $2.50 \mathrm{~b}$ \\
\hline EO L. sidoides & 16.55 e,f & $58.33 c$ & $12.94_{c}$ & $58.13 \mathrm{a}, \mathrm{b}, \mathrm{c}$ & $5.50 \mathrm{a}, \mathrm{b}$ \\
\hline$F_{2} L S$ & $23.85 b, c, d$ & $62,29 a$ & $44.41 a$ & $42.71 \mathrm{~d}$ & $0.00_{c}$ \\
\hline Nystatin/ & 29.62 a & - & - & - & - \\
\hline Chlorhexidine digluconate & - & $55.42 \mathrm{~d}$ & 37.65 a & $57.08 c$ & $1.50 \mathrm{~b}$ \\
\hline
\end{tabular}

AG: A. gratissima, CA: C. articulatus, CS: C. sativum, MG: M. glomerata, LS: L. sidoides. Values of 0.00 indicates any inhibition on biofilm formation. Values in the same column with different letters $(a-f)$ are significantly different $(p \leq 0,05)$ by Tukey Test.

\section{Results and discussion}

Oil and fractions yields

The EOs and fractions yields are presented in Tables 2 and 3, respectively, relative to mass of dry plant material. The highest oil yields were obtained from $L$. sidoides (4.67\%), M. piperita (2.22\%), C. winterianus (1.48\%), C. citratus $(1.13 \%)$ and A. gratissima (1.10\%).

\section{Antimicrobial assays}

The results obtained for MIC/MBC/MFC of the EOs against the oral microorganisms are shown in Table 2. According to Duarte et al. [17], the EOs presented strong to moderate antimicrobial activity against planktonic cells, with MIC values between 0.007 and $1.00 \mathrm{mg} / \mathrm{mL}$. The highest activities were observed for A. speciosa, C. sativum and C. zeilanicus EOs against C. albicans $(0.07 \mathrm{mg} / \mathrm{mL})$. Coriandrum sativum oil inhibited F. nucleatum and $S$. mitis at lowest MIC values $(0.015 \mathrm{mg} / \mathrm{mL}$ and $0.062 \mathrm{mg} / \mathrm{mL}$, respectively) compared with the other oils tested. S. guianenses and $M$. glomerata oils inhibited, respectively, the growth of $P$. gingivalis and S. sanguis at $0.062 \mathrm{mg} / \mathrm{mL}$.

According to the criteria previously mentioned, the oils from A. gratissima (AG), C. articulatus (CA), C. sativum (CS), L. sidoides (LS) and M. glomerata (MG) were fractionated and the fractions were submitted to antimicrobial assays. The MIC/MBC/MFC results from crude oils (EO) and fractions are shown in Table 3. The highest inhibitory and bactericidal effects presented by the fractions were observed for F2LS (Fraction 2 from L. sidoides) against $F$. nucleatum and S. mitis and for F1CA (fraction 1 from $C$. articulatus) and F4AG (fraction 4 from A. gratissima) against $P$. gingivalis and $S$. sanguis, respectively. However, all the fractions presented similar or lower activity than the crude oil against the microorganisms suggesting a synergistic action from the compounds present in crude oil.

The marked activity found for some oils in the present study was previously verified for bacteria such as Bacillus megaterium, B. cereus, S. piogenes, Escherichia coli and Proteus mirabilis (C. articulatus) and standards or clinical isolates of Candida spp (C. sativum) [25,26]. The oil from $L$. sidoides obtained in this study inhibited $S$. mitis and $S$. sanguis at MIC values higher than those observed by Botelho et al. [27] in an analogous study.

\section{Mode of action of the EOs and fractions on biofilm}

The results of MIC/MBC/MFC for the biofilms as well as the MBC/MFC:MIC ratio of the most active crude oils and fractions are shown in Table 4. The ratio calculation was adapted from Hafidh et al. [21]. According to the results, C. articulatus EO stood out, inhibiting all investigated species with the lowest MIC/MBC values. Similar activities were observed for the crude oil and the F2LS from $L$. sidoides against $S$. sanguis, and for A. gratissima oil against $S$. mitis biofilm. As expected, planktonic cells from all strains studied were more susceptible to the EOs (Table 2) when compared to biofilm (Table 4) as observed in previous studies to a great variety of antimicrobial agents $[28,29]$. Chandra [30] observed that antifungal agents used against $C$. albicans biofilms were much less active than against planktonic cells, and that the concentrations required to reach $50 \%$ inhibition of the metabolic activity were around 5 to 8 times higher. Also, Eucalyptus oil and its major component 1,8-cineole, when employed alone or combined with chlorhexidine digluconate against biofilms from several microorganisms cultures including C. albicans, showed better activities against planktonic cells [31]. The results confirm the effective action of 
Table 7 Biofilm Inhibition (\%) of the oral microorganisms in the presence of C. articulatus and A. gratissima EO

\begin{tabular}{|c|c|c|c|c|c|c|c|c|c|c|}
\hline \multirow{3}{*}{ Concentration } & \multicolumn{10}{|l|}{ Microorganism } \\
\hline & \multicolumn{2}{|c|}{ C.albicans CBS 562} & \multicolumn{2}{|c|}{ F. nucleatum ATCC 25586} & \multicolumn{2}{|c|}{ P. gingivalis ATCC 33277} & \multicolumn{2}{|c|}{ S. sanguis ATCC 10556} & \multicolumn{2}{|c|}{ S. mitis ATCC 903} \\
\hline & C. articulatus & Nystatin & C. articulatus & Chlorhexidine & C. articulatus & Chlorhexidine & C. articulatus & Chlorhexidine & A. gratissima & Chlorhexidine \\
\hline 1 & 28.08 & 29.62 & 61.67 & 55.42 & 43.53 & 37.65 & 63.96 & 57.08 & 9.00 & 1.50 \\
\hline 0.500 & 14.23 & 28.72 & 54.79 & 56.46 & 32.35 & 37.94 & 58.96 & 46.46 & 0.00 & 3.50 \\
\hline 0.250 & 22.69 & 20.77 & 60.42 & 55.21 & 28.24 & 35.59 & 54.17 & 55.83 & 0.00 & 0.00 \\
\hline 0.125 & 19.23 & 27.69 & 57.50 & 55.42 & 0.00 & 39.12 & 23.13 & 57.92 & 0.00 & 0.00 \\
\hline 0.062 & 21.54 & 23.08 & 49.17 & 53.54 & 0.00 & 37.06 & 7.29 & 56.25 & 0.00 & 0.00 \\
\hline 0.031 & 19.23 & 21.15 & 44.38 & 55.83 & 0.00 & 29.41 & 10.02 & 56.04 & 0.00 & 0.00 \\
\hline 0.015 & 19.62 & 13.08 & 40.21 & 55.21 & 0.00 & 13.82 & 10.63 & 53.54 & 0.00 & 0.00 \\
\hline 0.007 & 16.92 & 16.15 & 31.67 & 42.50 & 0.00 & 1.76 & 4.38 & 51.46 & 0.00 & 0.00 \\
\hline 0.003 & 14.62 & 0.00 & 0.00 & 52.92 & 0.00 & 0.00 & 0.00 & 47.08 & 0.00 & 0.00 \\
\hline 0.0019 & 17.69 & 0.00 & 0.00 & 48.33 & 0.00 & 0.00 & 0.21 & 50.63 & 0.00 & 0.00 \\
\hline 0.00097 & 4.62 & 0.00 & 0.00 & 53.96 & 0.00 & 0.00 & 0.00 & 27.08 & 0.00 & 0.00 \\
\hline 0.00048 & 0.00 & 0.00 & 0.00 & 54.17 & 0.00 & 0.00 & 3.54 & 18.33 & 0.00 & 0.00 \\
\hline
\end{tabular}

The values indicated in the table 0.00 demonstrated that don't have any inhibition on biofilm formation. 

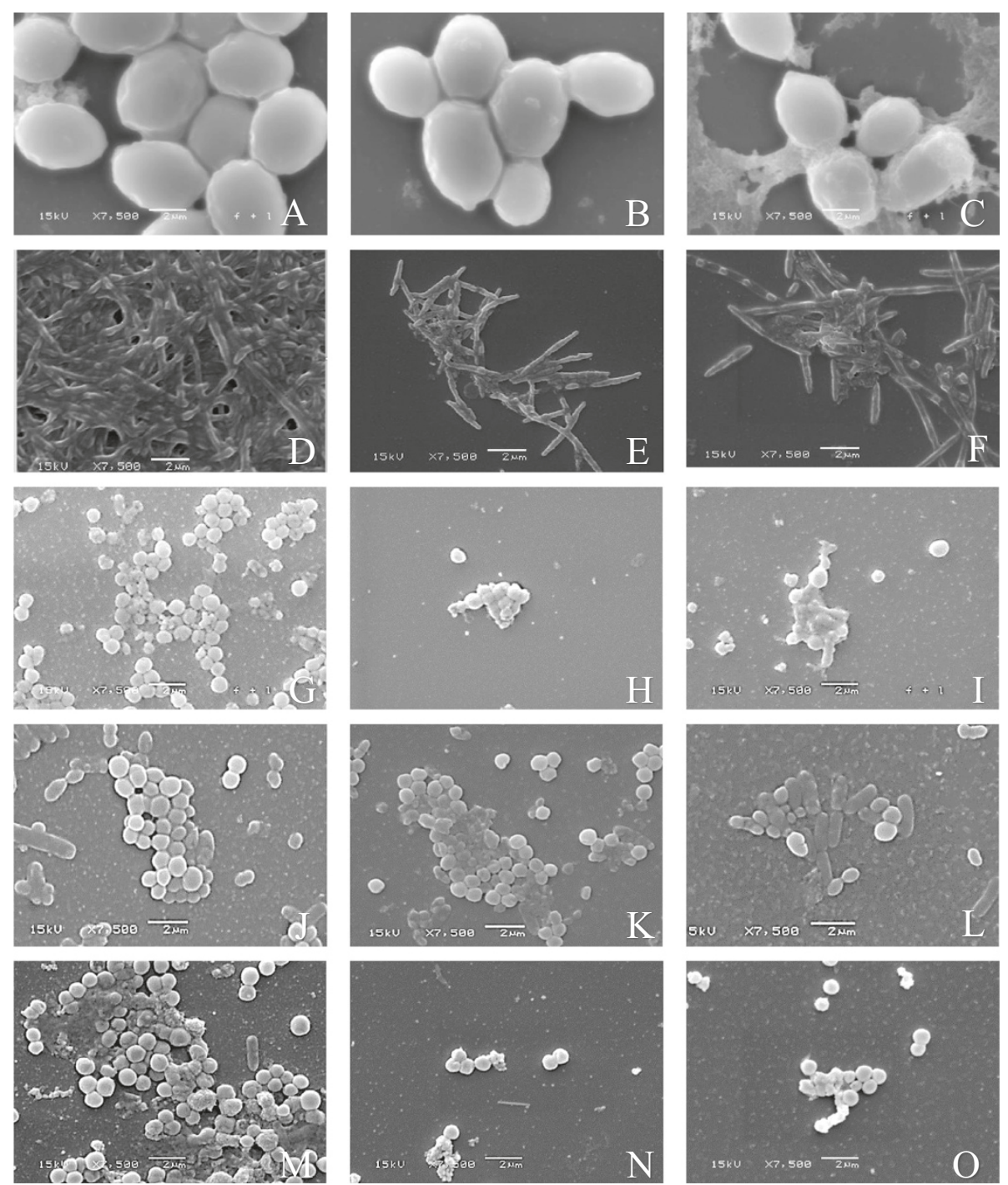

Figure 1 Scanning electron micrographs of biofilms - 7.500x. (A) C. albicans; (B) C. albicans in the presence of C. articulatus oil; (C) C. albicans in the presence of Nystatin; (D) F. nucleatum; (E) F. nucleatum in the presence of C. articulatus oil; (F) F. nucleatum in the presence of chlorhexidine digluconate. (G) P. gingivalis; (H) P. gingivalis in the presence of C. articulatus oil; (I) P. gingivalis in the presence of chlorhexidine digluconate; (J) S. mitis; (K) S. mitis in the presence of A. gratissima oil; (L) S. mitis in the presence of chlorhexidine digluconate; (M) S. sanguis; (N) S. sanguis in the presence of C. articulatus oil; (0) S. sanguis in the presence of chlorhexidine digluconato.

C. articulatus EO that exerted bactericide/fungicide action against all oral microorganisms studied. The mode of action observed for $C$. articulatus $\mathrm{EO}$ on the microorganisms studied can be related to the possible mechanisms of action presented by its major components, a- and b-pinene (Table 5) that showed be able to destroy cell integrity, and inhibit respiration and the ion transport processes, leading to cell death [32]. Besides, the $C$. articulatus compounds presented a considerable antibacterial effect, especially on a methicillineresistant Staphylococcus aureus and on Gram-positive and Gram-negative bacteria [33].
Regard to the inhibition of biofilm formation in the presence of $1 \mathrm{mg} / \mathrm{mL}$ of EOs and fractions (Table 6), the fraction F2LS and the oils from A. gratissima and $C$. articulatus demonstred the highest inhibition, respectively, on F. nucleatum (62.29\%) and P. gingivalis (44.41\%), S. mitis (9\%) and C. albicans (28.08\%) and S. sanguis (63.96\%). Since no significative difference $(\mathrm{p} \leq 0,05)$ was observed between the action of the $C$. articulatus crude oil and the fraction F2LS against $F$. nucleatum and $P$. gingivalis biofilms, the crude oils from $C$. articulatus and A. gratissima was chosen for further assays in the range of $0.0048-1 \mathrm{mg} / \mathrm{mL}$ (Table 7). In this condition, A. gratissima inhibited the 
formation of $S$. mitis biofilm only at $1 \mathrm{mg} / \mathrm{mL}$ (9\%), even though this activity was superior to that of the chlorhexidine. On the other hand, the biofilm inhibition by $C$. articulatus oil was proportional to the concentration employed, and also similar or superior to standards used.

\section{Scanning electronic microscopy (SEM)}

Morphological alterations in the microorganisms cells and biofilm arrangement exposed to the EOs were investigated by SEM (Figure 1). Through the SEM images was possible to observe reduction of biofilm formation and changes in the conformational structure probably due to a decrease in the cells adherence and consequently in the biofilm formation. These changes were also observed by Galvão et al. [34] whose tested the action of the EOs and bioactive fractions against S. mutans. However, apparently the EOs do not appear to have caused changes at cellular level. The decrease in the ability to form biofilm can be explained by the occurrence of various resistance mechanisms, which are still not completely understood given by the expression of resistance genes, and which can be attributed to a decrease in the rate of cell growth, particularly to those situated close to the adherence surface [35].

\section{Chemical composition of the active EOs and fractions}

The major compounds identified in the most active oils and fractions are shown in Table 5. The analysis showed the presence of derived from aliphatic alchools in the $C$. sativum oil such as 1-decanol, E-2-decen-1-ol, 2 dodecen-1-ol, E-2-tetradecen-1-ol, E-3-hexen-1-ol, previously described in this aromatic specie commonly used in Brazilian culinary [36]. Anti-Candida activity of these compounds was comproved by Furletti et al. [25], which tested standards and correlated the activity to Z-2-hexen-ol, E-2-hexen-ol, E-3-hexen-ol and 1-decanol.

The main compounds identified in the other active oils were b-pinene, E-pinocamphone, E-caryophyllene, $E$ pinocarveol acetate and guaiol in A. gratissima and, a-pinene, a-bulnesene, $E$-pinocarveol and a-copaene in C. articulatus. Regarding to these compounds several authors have already shown their efficacy against both Gram-positive and Gram-negative bacteria [37-40].

The action mechanisms of the EOs and its compounds are not yet fully elucidated, but includes the inhibition of proton motive force and electron transfer and, consequently inhibition of the respiratory chain, mechanism of transport and decrease in substrate oxidation and membrane damage, leading to cell death [41-44]. Further studies should be developed in order to investigate the mechanisms by which the oils and their compounds acted on the oral microorganisms in the present study.

\section{Conclusion}

The action of $C$. sativum EO against planktonic cells of C. albicans stood out from others EOs showing the lowest MIC values against the oral microorganisms investigated. The crude $C$. articulatus oil showed the highest inhibition on the cells adherence and consequently in the biofilms formation. The oils from these plants can be considered as new sources of antibacterial agents with great potential against oral pathogens.

\section{Competing interests}

The authors declare that they have no competing interests.

\section{Authors' contributions}

SMFB performed the antimicrobial activity and biofilm assays, chemical fractionation, electron microscopy and participated in drafting the paper: LCCG extraction of essential oils, VFFG participated in the testing of biofilm assays; AS chemically evaluated oils and fractions through thin layer chromatography; GMF guided the entire process of selection of plants to be studied and recommended procedures for extraction of essential oils; VLGR guided procedures relating to chemical fractionation; SMA participated in the chemical analysis of oils and fractions; RMTD support in the antimicrobial activity assays and in writing the paper and applied statistical tests; PLR design and execution of the study; MCTD guiding the antimicrobial activity and biofilm assays, final approval of the study and the project coordinator. All authors read and approved the final manuscript.

\section{Acknowledgements}

The authors thank FAPESP (São Paulo Research Foundation - Brazil) and CNPq (National Council for Scientific and Technological Development - Brazil) for the financial support.

\section{Author details}

${ }^{1}$ Department of Physiological Sciences, Piracicaba Dental School, University of Campinas, (UNICAMP), 901 Limeira Av, Zip Code 13414-018 Piracicaba, SP, Brazil. ${ }^{2}$ Chemical, Biological and Agricultural Pluridisciplinary Research Center (CPQBA), University of Campinas (UNICAMP), Box. 6171, Zip Code: 13081-970 Campinas, SP, Brazil. 'Department of Agri-food industry, Food and Nutrition, Escola Superior de Agricultura "Luiz de Queiroz", University of São Paulo (USP), 11 Pádua Dias Avenue, Zip Code: 13418-900 Piracicaba, SP, Brazil.

Received: 12 December 2013 Accepted: 29 September 2014

Published: 18 November 2014

\section{References}

1. Kolenbrander PE: Oral microbial communities: biofilms, interactions, and genetic systems. Annu Rev Microbiol 2000, 54:413-437.

2. Spratt PA, Pratten J: Biofilms and the oral cavity. Rev Environ Sci Biotechnol 2003, 2:463-467.

3. Kolembrander PE: Multispecies communities: interspecies interactions influence growth on saliva as sole nutritional source. Int J Oral Sci 2011, 3(Suppl 2):49-54.

4. Marsh PD: Dental plaque: biological significance of a biofilm and community life-style. J Clin Periodontol 2005, 32:7-15.

5. Bernimoulin JP: Recent concepts in plaque formation. $J$ Clin Periodontol 2003, 30(Suppl 5):7-9.

6. Marsh PD: Are dental diseases examples of ecological catastrophes? Microbiology 2003, 149:279-294.

7. Filoche SK, Soma K, Sissons CH: Antimicrobial effects of essencial oils in combination with chlorexidine digluconate. Oral Microbiol Immunol 2005 20(Suppl 4):221-225

8. Rosenthal S, Spangberg L, Safavi K, Conn F: Chlorhexidine substantivity in root canal dentin. Oral Surg Oral Med Oral Pathol Oral Radiol Endod 2004, 98:488-492.

9. Zheng $\mathrm{CY}$, Wang $\mathrm{ZH}$ : Effects of chlorhexidine, listerine and fluoride listerine mouthrinses on four putative root-caries pathogens in the biofilm. Chin J Dent Res 2011, 14(Suppl 2):135-140. 
10. Lang G, Buchbauer G: A review on recent research results (2008-2010) on essential oils as antimicrobials and antifungals. Rev Flavour Fragr J 2012, 27(Suppl 1):13-39.

11. Calsamiglia S, Busquet M, Cardozo PW, Castillejos L, Ferret A: Invited review: essential oils as modifiers of rúmen microbial fermentation. J Dairy Sci 2007, 6(Suppl 90):2580-2595.

12. Khan A, Ahmad A, Akhtar F, Yousuf S, Xess I, Khan LA, Manzoor N: Induction of oxidative stress as a possible mechanism of the antifungal action of three phenylpropanoids. FEMS Yeast Res 2011, 11:114-122.

13. Cha JD, Jeong MR, Jeong SII, Moon SE, Kil BS, Yun SII, Lee KY, Song YH: Chemical composition and antimicrobial activity of the essential oil of Cryptomeria japonica. Phytother Res 2007, 21:295-299.

14. Maggi F, Cacchini C, Cresci A, Coman MM, Tirillini B, Sagratini G, Papa F, Vittori S: Chemical composition and antimicrobial activity of Hypericum hircinum L. Subsp. majus essential oil. Chem Nat Compd 2010, 1(Suppl 46):125-129.

15. Nascimento PFC, Alviano WS, Nascimento ALC, Santos PO, Arrigoni-Blank MF, Jesus RA, Azevedo VG, Alviano DS, Bolognese AM, Trindade RC: Hyptis pectinata essential oil: chemical composition and anti-Streptococcus mutans activity. Oral Dis 2008, 14:485-489.

16. Gorelov VE, Aksel'rod LS, Migalisnkaya LN: An investigation of the hydraulics and effectiveness of fractionation columns with sieve packing. Chem Petrol Eng 1971, 7(Suppl 3):211-214.

17. Duarte MCT, Figueira GM, Sartoratto A, Rehder VL, Delarmelina C: Anti-Candida activity of Brazilian medicinal plants. J Ethnopharmacol 2005, 97(Suppl 2):305-311.

18. Adams RP: Identification of Essential Oils Components by Gas Chromatography/Mass Spectrometry, Volume 4. USA: Allured publishing Edited by Carol Stream III; 2007

19. Clinical and Laboratory Standards Institute: Methods for Dilution Antimicrobial Susceptibility Tests for yeast. In Approved Standard CLSI document M27-A2. Volume 22. 2nd edition. Edited by FortWayne Ind USA; 2002

20. Clinical and Laboratory Standards Institute: Methods for Dilution Antimicrobial Susceptibility Tests for Bacteria that Grow Aerobically. In Approved Standard CLSI document M07-A6. Volume 26. 6th edition. Edited by FortWayne Ind USA; 2005.

21. Hafidh RR, Abdulamir AS, Vern LS, Bakar FA, Abas F, Jahanshiri F, Sekawi Z: Inhibition of growth of highly resistant bacterial and fungal pathogens by a natural product. Open Microbiol J 2011, 5:96-106.

22. Niu C, Gilbert ES: Colorimetric method for identifying plant essential Oil components that affect biofilm formation and structure. Appl Environ Microbiol 2004, 70(Suppl 12):6951-6956

23. Djordjevic $D$, Wiedmann M, McLandsborough LA: Microtiter plate assay for assessment of Listeria monocytogenes biofilm formation. Appl Environ Microbiol 2002, 68(Suppl 6):2950-2958.

24. Hawser SP, Douglas LJ: Biofilm formation by Candida species on the surface of catheter materials in vitro. Infect Immun 1994, 62(Suppl 3):915-921.

25. Furletti VF, Teixeira IP, Obando-Pereda G, Mardegan RC, Sartoratto A, Figueira GM, Duarte RMT, Rehder VLG, Duarte MCT, Höfling JF: Action of Coriandrum sativum L. essential oil upon oral Candida albicans biofilm formation. Evid Based Complement Alternat Med 2011, 1-9. http://dx.doi.org/10.1155/2011/985832.

26. Oladusu IA, Usman LA, Olawore NO, Atata RF: Antibacterial activity of rhizomes essential oils of types of Cyperus articulatus Growing in Nigeria. Ad Bio Res 2011, 5(Suppl 3):179-183.

27. Botelho MA, Nogueira NAP, Bastos GM, Fonseca SGC, Lemos TLG, Matos FJA, Montenegro D, Heukelbach J, Rao VS, Brito GAC: Antimicrobial activity of the essential oil from Lippia sidoides, carvacrol and thymol against oral pathogens. Braz J Med Biol Res 2007, 40:349-356.

28. Donlan RM, Costerton JW: Biofilms: survival mechanisms of clinically relevant microorganisms. Clin Microbiol Rev 2002, 15:167-193.

29. Hope CK, Wilson M: Analysis of the effects of chlorhexidine on oral-biofilm vitality and structure based on viability profiling and an indicator of membrane integrity. Antimicrob Agents Ch 2004, 48:1461-1468.

30. Chandra J: Antifungal resistance of Candida biofilms formed on denture acrylic in vitro. J Dent Res 2003, 80:903-908.

31. Hendry ER, Worthington T, Conway BR, Lambert PA: Antimicrobial efficacy of eucalyptus oil and 1,8-cineole against microorganisms grow in planktonic and biofilm cultures. J Antimicrob Chemother 2009, 64:1219-1225.
32. Carson CF, Me BJ, Riley TV: Mechanism of action of Melaleuca alternifolia (tea tree) oil on Staphylococcus aureus determined by time-kill, lysis, leakage, and salt tolerance assays and electron microscopy. Antimicrob Agents Chemother 2002, 46:1914-1920.

33. Martins A, Salgueiro LR, Gonçalves MJ, Proença SC, Vila A, Canigueral R: Essential oil composition and antimicrobial activity of Santiria trimera bark. Planta Med 2003, 69:77-79.

34. Galvão LCC, Furletti VF, Bersan SMF, Cunha MG, Ruiz ALTG, Carvalho JE, Sartoratto A, Rehder VLG, Figueira GM, Duarte MCT, Ikegaki M, Alencar SM, Rosalen PL: Antimicrobial activity of essential oils against streptococcus mutans and their antiproliferative effects. J Evid Based Complementary Altern Med 2012, 40:1-12. http://dx.doi.org/10.1155/2012/751435.

35. Douglas LJ: Candida biofilms and their role in infection. Trends Microbiol 2004, 11(Suppl1):30-36.

36. Begnami AF, Duarte MCT, Furletti $V$, Rehder VLG: Antimicrobial potential of Coriandrum sativum L. against different Candida species in vitro. Food Chem 2010, 118:74-77.

37. Dorman H, Deans S: Antimicrobial agents from plants: antibacterial activity of plant volatile oils. J Appl Microbiol 2000, 88:308-316.

38. Mercier B, Prost J, Prost M: The essential oil of turpentine and its major volatile fraction (alpha-and beta-pinenes): a review. Int J Occup Med Environ Health 2009, 22:331-342.

39. Delaquis PJ, Stanich K, Girard B, Mazza G: Antimicrobial activity of individual and mixed fractions of dill, cilantro, coriander and eucalyptus essential oils. Int J Food Microbiol 2001, 74:101-109.

40. Kim K, Kim Y, Yu H, Jeong S, Cha J, Kil B, You Y: Antibacterial activity and chemical composition of essential oil of Chrysanthemun boreal. Planta Med 2003, 69:274-277.

41. Silva F, Ferreira S, Queiroz JA, Domingues FC: Coriander (Coriandrum sativum L.) essential oils: its antibacterial activity and mode of action evaluated by flow cytometry. J Med Microbiol 2011, 60(Suppl 10):1479-1486.

42. Khan A, Ahmad A, Akhtar F, Yousuf S, Xess I, Khan LA, Manzoor N: Ocimum sanctum essential oil and its active principles exert their antifungal activity by disrupting ergosterol biosynthesis and membrane integrity. Res Microbiol 2010, 161:816-823.

43. Pavithra PS, Sreevidya N, Verma RS: Antibacterial activity and chemical composition of essential oil of Pamburus missionis. J Ethnopharmacol 2009, 124:151-153.

44. Magwa ML, Gundidza M, Gwerua N, Humphrey G: Chemical composition and biological activities essential oil from the leaves of Sesuvium portulacastrum. J Ethnopharmacol 2006, 103:85-89.

doi:10.1186/1472-6882-14-451

Cite this article as: Bersan et al: Action of essential oils from Brazilian native and exotic medicinal species on oral biofilms. BMC Complementary and Alternative Medicine 2014 14:451.

\section{Submit your next manuscript to BioMed Central and take full advantage of:}

- Convenient online submission

- Thorough peer review

- No space constraints or color figure charges

- Immediate publication on acceptance

- Inclusion in PubMed, CAS, Scopus and Google Scholar

- Research which is freely available for redistribution 